\title{
IN SEARCH OF THE PARTY: THE COMMUNIST PARTY, THE COMINTERN, AND THE PEASANT REBELLION OF 1932 IN EL SALVADOR*
}

\begin{abstract}
The rebellion of 1932 in El Salvador is commonly described in the context of communism and the leadship role of the Communist Party of El Salvador (PCS). Relying on previously unavailable archive materials from Russia and El Salvador, the present article demonstrates that the PCS played a limited role in the rebellion. Factional infighting and a strategy that collided with social realities in western El Salvador combined to inhibit PCS influence among western peasants. The evidence suggests that Indian communities were at the forefront of the rebellion, as an extention of their long history of political mobilization.
\end{abstract}

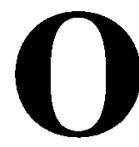

n the 9th of February 1932, El Salvador's Minister of Health telegraphed the following instructions to the municipalities of Sonsonate Department, the locus of a recent peasant uprising:

In regard to the necessary sanitary measures that should be followed relative to the new internments to be conducted ... past burials were carried out in trenches of variable dimensions, up to thirty meters long, one to two meters wide, and one and a half to two meters deep. This office thinks it is necessary to make the dimensions uniform for reasons of health. The accumulation of only fifty corpses in a single grave allows for better decomposition and less absorption into the soil. Even better would be isolated graves, two cubic meters in size, in which no more than

\footnotetext{
* Research and writing were made possible by grants from Fulbright, the Academy for Educational Development, the Albert Beveridge Committee of the American Historical Association, and the History Associates at the University of California, Santa Barbara. I would like to thank Fernando Rocchi, Aldo Lauria, Barry Carr, Héctor Lindo-Fuentes, David Rock, Virginia Tilley, Pat Bean and the anonymous reviewers at The Americas for reading drafts of this paper, and also Carrie Simon for her assistance in Russia. A small portion of the research in this article appeared in Spanish as: "Los archivos de Moscú: una nueva apreciación de la insurrección del 32," Tendencias, (El Salvador), 3:44 (septiembre, 1995): 28-31.
} 


\section{Area of 1932 Rebellion}

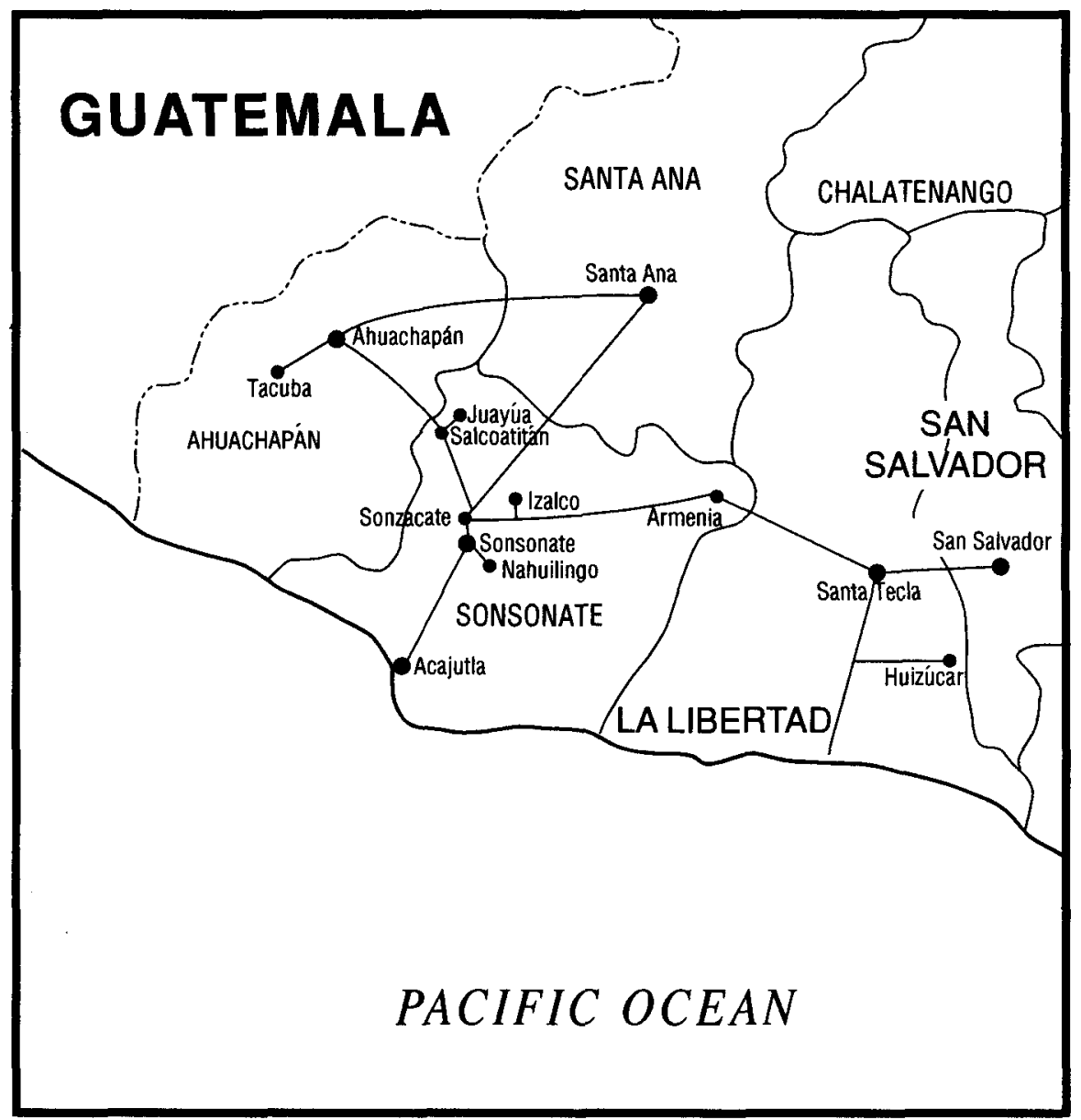

HIGHLINE COMMUNITY COLLEGE PUBLICATIONS

eight to ten corpses would be placed. This information is particularly important for the municipalities of Juayúa, Nahuizalco and Izalco. ${ }^{1}$

The Minister's impassive tone belies the tragic drama that inspired his instructions. Late in the evening of January 20th, 1932, peasants armed

\footnotetext{
${ }^{1}$ Circular from the Minister of Health to the Alcaldes of Sonsonate Department, February 9 , 1932, Archivo General de la Nación (AGN), Ministerio de Gobernación (MG), Sección Sonsonate (SS), Box 3.
} 
with machetes and a few old shotguns began to attack municipalities in the coffee-growing region of western El Salvador. Over the next few days the insurgency grew to include as many as several thousand rebels who attacked more than one dozen municipalities and gained control over half of them-including the important and populous townships of Juayúa, Nahuizalco and Izalco in Sonsonate Department. The rebels targeted symbols of local power, especially local élites and their property. They retained control of the occupied villages for up to four days and in the process killed approximately fifty people. ${ }^{2}$ One report on the damage reads: "Communist hoards have caused great damage in the municipalities of Izalco, Juayúa, Salcoatitán, Nahuizalco and Sonzocate. The Municipal Buildings of Nahuizalco, Salcoatitán and Sonzocate were all burned, destroying the archives. The contents of the vaults were stolen. In Juayúa and Izalco, the rebels caused considerable damage, they burned records and parts of the archives."3

The government, under the control of General Maximiliano Hernández-Martínez, who had come to power just six weeks prior in a coup, responded to the uprising with decisive brutality. When Martíne $z^{4}$ and his fellow commanders appreciated the extent of the rebellion, they sent reinforcements to Sonsonate on the morning of January 25 th. The next few days have come to be known simply as la matanza (the massacre). Military units swept through the insurgent zones from their staging point in Sonsonate City and regained control over the region in less than one week. In the process they meted out violence on a colossal scale. ${ }^{5}$ Estimates of the total number of peasants killed during the crackdown range from fewer than ten thousand to as many as thirty thousand (in a country of 1.5 million people). The formidable task of burying the dead was left to overwhelmed local officials, and,

\footnotetext{
${ }^{2}$ Descriptions of the revolt can be found in Héctor Pérez Brignoli, "Indians, Communists and Peasants: The 1932 Rebellion in El Salvador," in William Roseberry, et. al., eds., Coffee Society and Power in Latin America (Baltimore: The Johns Hopkins University Press, 1995), pp. 232-61; Thomas Anderson, Matanza: El Salvador's Communist Revolt of 1932 (Lincoln: University of Nebraska Press, 1971); and Joaquín Méndez, Los sucesos comunistas en El Salvador (San Salvador: Imprenta Funes y Ungo, 1932).

${ }^{3}$ Governor of Sonsonate Department to the National Accountant, February 4, 1932, in Notas del Ministerio de Gobernación, February, 1932, AGN, MG, unclassified box.

${ }^{4}$ Martínez went by his maternal name.

${ }^{5}$ A rare eye-witness account of a the slaughter comes from a North American missionary who was stationed in Juayúa and described the military regaining control of the village virtually without resistance, and then gathering the local peasants in the plaza before taking them to the outskirts of town to be shot. Roy MacNaught "The Horrors of Communism in Central America," Central American Bulletin, (Dallas, TX) no. 181, (March, 1932).
} 
more than one week later corpses were still exposed. The health risk prompted the Minister of Health to send his telegram of February 9th.

The uprising and subsequent matanza constitute watersheds in El Salvadoran history, not only for scholars concerned with the political and intellectual ramifications of such events, but also for the mass of $\mathrm{El}$ Salvador's population which holds the memory of 1932 firmly in its collective consciousness. The meaning of 1932, however, remains a highly partisan matter. For the political left, 1932 symbolizes the intransigence of the coffee barons and the brutality of the military in the face of popular mobilization. For the political right, 1932 confirms its çlaims of a genuine communist threat. That 1932 serves as a benchmark for political identity in El Salvador is made evident by the nomenclature of opposing parties in the civil war of 1980-1992. One of the notorious death squads chose as its namesake General Martínez, while the coalition of guerrilla armies - the FMLN-named itself after Farabundo Martí, a member of the Communist Party of El Salvador (PCS) who was executed in February 1932 for his suspected involvement in the rebellion.

Despite their profound differences, the left and the right agree on one fundamental aspect of 1932 -that it was communist in nature; meaning that the PCS inspired it, organized it and led the peasant rebels in the assaults. Both sides mutually benefit from making this claim. The left bolsters its image as the vanguard of the masses, regardless, or perhaps because of the tragic consequences of 1932. And the right is able to portray itself as the successor to those who saved $\mathrm{El}$ Salvador from communism. Scholars too have emphasized the role of the PCS in the rebellion, sometimes for their own political reasons, but more often because evidence did not indicate otherwise. Relevant archival materials both inside and outside El Salvador were off-limits.

Current scholarship on 1932 has been forced to rely heavily on a handful of sources, particularly the dramatic account of Miguel Mármol, a high-ranking party member who survived a firing squad during the matanza. ${ }^{6}$ Mármol places the PCS at the center of his account, as do the few other previously available sources, including newspapers articles, U.S. and British foreign service reports, and a report on the aftermath of the rebellion by Joaquín Méndez, a Salvadoran journalist

\footnotetext{
${ }^{6}$ Dalton, Roque, Miguel Marmol (Willimantic, CT: Curbstone Press, 1987), originally published as Miguel Mármol: los sucesos de 1932 en El Salvador (San José: EDUCA, 1972).
} 
sympathetic to the military. These sources uniformly refer to the rebels as communists and portray the rebellion as a communist conspiracy. Scholars staying true to this evidence tended to focus on the PCS. One example is Thomas Anderson, author of Matanza, the first substantive history of 1932, who made the party the core of his research and subtitled his book "El Salvador's Communist Revolt of 1932." Another scholar credits the Communist International as having had a "determining influence" on the PCS and the outbreak of revolt. ${ }^{8}$ A third scholar argues that the rebellion occurred because communism became "hegemonic" among the western peasantry between 1930 and 1932. ${ }^{9}$ With few exceptions, the communist-centered approach dominates received wisdom. ${ }^{10}$ Two exceptions are Héctor Pérez, who shifted the focus onto the Indian communities, and Rodolfo Cerdas, who questioned the importance of the PCS in his brief study of Farabundo Martí. ${ }^{11}$ But both scholars were hampered by a lack of evidence.

My intent in this article is not to find fault with prior scholarship, for it has advanced our knowledge about El Salvador and 1932. Rather, I bring to light new evidence from recently opened archives in Russia and El Salvador that suggests the role of the PCS in 1932 has been

\footnotetext{
${ }^{7}$ Anderson, Matanza.

${ }^{8}$ Rodolfo Cerdas-Crúz, The Communist International in Central America, 1920-1936 (Houndsmill: Macmillan Press, 1993), p. 126.

${ }^{9}$ Patricia Alvarenga "Reshaping the Ethics of Power: A History of Violence in Western Rural El Salvador, 1880-1932," Ph.D. Dissertation, University of Wisconsin, 1994, p. 322. This work was published in similar form as Cultura y ética de la violencia: El Salvador 1880-1932 (San José: EDUCA, 1996).

${ }^{10}$ The extent to which this interpretation dominates the current state of knowledge on 1932 is, made evident by works relying upon secondary evidence. In his study of the Comintern in Latin America, Manuel Caballero, for instance, refers to the 1932 rebellion as "the first Communist insurrection in the Western hemisphere." Interestingly, Caballero de-emphasized the role of the Comintern: "The Comintern had practically nothing to do with it. As far as is known, it seems to have been a spontaneous initiative of the Salvadorean Communists." Manuel Caballero, Latin America and the Comintern, 1919-1943 (Cambridge: Cambridge University Press, 1986), p. 52. See also pp. 2 and 9. For other works which emphasize the role of the PCS see Jeffery Paige, Coffee and Power: Revolution and the Rise of Democracy in Central America (Cambridge, MA: Harvard University Press, 1997); Jorge Arias Gómez, Farabundo Martí: esbozo biográfico (San José: EDUCA, 1972); and Alfredro Schlesinger, Revolución comunista: Guatemala en peligro? (Guatemala: Unión Tipográfica Castañeda, Avila y Cia., 1946).

${ }^{11}$ Pérez, "Indians, Communists;" and Rodofo Cerdas Crúz, "Farabundo Martí, la internacional comunista y la insurreción salvadoreña de 1932," Estudios de Centro de Investigación y Adiestramiento Político Administrativo, no. 7, (septiembre 1982). Although based on secondary materials, other scholars have also tried to de-emphasize the focus on the PCS. See, for instance, Liisa North, Bitter Grounds: Roots of Revolt in El Salvador (Toronto: Between the Lines, 1981).
} 
overstated. The collapse of the Soviet Union and the end of war in El Salvador eroded restrictions to archives. ${ }^{12}$ The documentation from Russia, which constitutes a main source for this article, surfaced after 1991 when the Russian government began declassifying the enormous documentary record of the former Soviet Union. One of the newlyopened archives is that of the Comintern, located on the third and fourth floors of the Center for the Study and Preservation of Documents of Recent History. ${ }^{13}$ Contained therein is the correspondence between the Third International and its affiliated communist parties and labor unions during the 1920s and 1930s. The archive contains materials produced both in Russia and in countries with which the Comintern corresponded because affiliates were required to send reports and documentation for analysis. Materials which likely would have been destroyed had they remained in El Salvador ended up safely in Moscow. The new evidence tells us, in the words of high-ranking PCS members themselves, that the party had little to do with the rebellion of 1932 .

To fully appreciate this evidence we must examine the party's early growth because its origins shaped its capacity, or lack thereof, to organize a revolt on the scale of 1932. This article is divided into four sections, the first three of which correspond to the party's chronological stages. The first section describes the formation of the PCS in March 1930 and its subsequent maturation. The second examines the party's attempt to organize the western peasantry in the latter half of 1931. The third details the party's response to the rebellion in January 1932. The final section offers a brief case study of the village of Nahuizalco. One consequence of the focus on the PCS has been a failure to examine the rebels on their own terms. The evidence from Nahuizalco shows that the Indians had a long history of autonomous political mobilization and that the rebellion erupted amidst ethnicbased political conflicts. In a brief conclusion, I place the Salvadoran case in a comparative context.

I suggest that the PCS was a peripheral actor in 1932 because it had virtually no organizational base in the west. During the first year of its

\footnotetext{
${ }^{12}$ For a description of the opening of archives in El Salvador see Aldo Lauria, "Historical Research and Sources on El Salvador," Latin American Research Review 30:2 (1994), 151-76.

${ }^{13}$ For a description of the archive and the process of gaining access to it see Erik Ching, "A Central Americanist in Russia's Comintern Archive," Latin American Labor News 14 (1996), 7-10. A more extensive but unpublished description is Erik Ching and Jussi Pakkasvirta, "Latin America in the Comintern Archive," on review at the Latin American Research Review.
} 
existence the party was bogged down by factional infighting. When it eventually turned its attention to the west in mid-1931, it was too late to win the hearts and minds of peasants who were predisposed to reject the leadership of outsiders.

\section{PARTY Formation}

The origin of El Salvador's communist party lay in a pre-existing trade union movement led by the Federación Regional de Trabajadores Salvadoreños (FRTS). Unlike Mexico and Argentina, where trade unions existed by the late nineteenth century, the first labor unions did not appear in El Salvador until the late 1910s. The first sizable strike occurred in 1917 and by 1924 enough unions had come into existence that they could unite to form the FRTS. From its base in San Salvador, the FRTS coordinated union activity and organized new unions. By 1929 it had thirty-one affiliates, but nineteen of them were located in just three cities-San Salvador, Santa Ana and Ahuachapán-giving the union a decidely urban bent. ${ }^{14}$ The Comintern took a mild interest in El Salvador just as the FRTS was coming into existence. Moscow had only nominal relations with Central America at the time, having made contact with Guatemala through the Communist Party of Mexico (PCM). ${ }^{15}$ The Comintern's delayed interest in Central America was to be expected. Its Marxist-based ideology, that the engine of social revolution was the industrial proletariat of Europe, simply did not grant priority to the small, rural nations of Central America. ${ }^{16}$ The Comintern invested a minimum of resources when it did eventually reach out to El Salvador in 1925. Instead of incurring the cost of sending agents, it relied upon the mail. The Comintern sent

\footnotetext{
${ }^{14}$ For descriptions of the FRTS and the early history of labor organizing in El Salvador see Aristides Larín, Historia del movimiento sindical de El Salvador (San Salvador: Editorial Universitaria, 1971); Rafael Menjívar, Formación y lucha del proletariado industrial salvadoreño (San Salvador: UCA Editores 1987); Antonio Murga Frassinetti, Economia agraria y movimiento obrero en Centroamérica, 1850-1933 (Iztapalapa: Universidad Autonoma Metropolitana, 1984); and Dalton, Miguel Marmol. The information on the number of unions in the FRTS in 1929 comes from a list sent to the Comintern by the FRTS, Archive of the Comintern (AC), Fond 534, Opis 7, Inventory 455, p. 7; hereafter abreviated 534:7:455, 7.

${ }^{15}$ Arturo Taracena, "El primer partido comunista de Guatemala (1922-1923): diez años de una historia olvidada," Anuario de Estudios Centramericanos 15:1, (1989), 49-63.

${ }^{16}$ Good sources on the strategic outlook of the Comintern include, Degras, Jane, The Communist International, 1919-1943, 3 Vols., (NY: Oxford University Press, 1956-65); Kevin Mcdermott and Jeremy Agnew The Comintern: A History of International Communism from Lenin to Stalin (NY: St. Martin's Press, 1997), Chapters 1 and 2; Drochkovitch, Milorad, ed., The Revolutionary Internationals, 1864-1943 (Stanford: Stanford University Press, 1966), Part III.
} 
letters of introduction to any labor organization in El Salvador for which it could find an address. Most of these letters were sent through secondary offices in New York and Paris, usually under the cover of the Confederación General de Trabajadores (CGTU). The letters expressed a polite interest in learning about union activity and establishing correspondence. One letter to a shoeworkers union in San Salvador began, "Dear Comrades, As of yet we do not have many relations with union organizations oriented towards class struggle in San Salvador, the state of which we also are insufficiently informed." 17 It is not clear where the Comintern got its addresses, for some of the letters went to defunct mutual aid societies. ${ }^{18}$ Eventually the Comintern contacted the FRTS and a steady correspondence began. ${ }^{19}$ The FRTS at that time was not a revolutionary organization. Its leaders were reformists who did not believe in overthrowing the system in a revolution. Later party documents claim that the union was then receiving a subsidy of $\$ 1,000$ per month from the government, but this amount seems high and corroborating evidence has yet to be found. ${ }^{20}$ Despite its lack of radicalism, the FRTS was the main labor union in El Salvador and the Comintern wisely maintained contact. From this correspondence we learn of a split within the FRTS that would culminate in the formation of the communist party.

Sometime around 1928 a small radical faction emerged within the ranks of the FRTS. It consisted of a few young members who made their debut in March 1929 at the Fifth Annual Congress by establishing a subcommittee called the Congress of Workers and Peasants (Congreso Obrero y Campesino) with a seven-member executive council. ${ }^{21}$ The Congress's inagural charter declared itself opposed to all forms of "bourgeois politics" and in favor of social revolution. The members referred to one another as "militant" and were expected to uphold

\footnotetext{
${ }^{17}$ To the Unión de Zapateros, San Salvador, from the Secrétariat International, Paris, January 11, 1928, AC, 534:6:128, 5 .

${ }^{18}$ The various letters are found in AC 534:7:455; 534:6:128; and 534:6:128.

${ }^{19}$ Initial correspondence went through a intermediary offices in Europe, and in some cases directly through Moscow. After the establishment of the Caribbean Bureau (Buró del Caribe) in 1929, most correspondence went through its offices in New York City.

${ }^{20}$ Contained in Report on El Salvador and Guatemala from Anaya to the Buró del Caribe, April 9, 1931, AC, 500:1:5, 18.

${ }^{21}$ Sources do not reveal the membership of the Congress, but it probably did not exceed three dozen persons.
} 
radical values or face disciplinary action. The Congress also established direct contact with the Comintern. ${ }^{22}$

The emerging radicalism of the Congress was made evident later that year when five members were sanctioned, two of whom, Gumercindo Ramírez and Raul Monterrosa, had served on the executive council. The Congress's press releases declared that the sanctions extended from misappropriation of funds. But internal documents reveal that the accused actually were being punished for affiliating with "objectionable" organizations. Monterrosa wrote a public defense confirming this. He claimed that the charge of financial wrongdoing was phony and that he and the others were being sanctioned for maintaining relations with the Confederation of Pan American Workers (COPA), an organization the Congress had deemed "bourgeois" because of its affiliation with the U.S.-based American Federation of Labor (AFL). In his letter Monterrosa also vilified the Congress for dividing the labor movement with a radical agenda. ${ }^{23}$

In the midst of this conflict over the expulsions, the Congress further advanced its radical agenda. Its members denounced the urban bias of the FRTS and declared their intention to shift the focus to the countryside and organize "all the workers of the nation," especially the coffee laborers in the west. ${ }^{24}$ In their statement they made clear that they understood El Salvador to be an agricultural nation where the masses lived in the countryside and thus the revolution must begin there.

The Congress's declaration marks an important moment in the early history of radicalism in El Salvador. As one of the first articulated calls by urban radicals for rural organizing, it blazed a trail that subsequent parties would follow, in particular the communist party after its formation in March, 1930. However, the declaration was more an assertion of principles than a plan of action, for the Congress was in no position to organize rural workers. It was still little more than a hand-

\footnotetext{
${ }^{22}$ The documents relating to the Congress are found in AC, 534:7:455. The Congress also is referred to many times in the first extensive document put out by the PCS in May 1930, AC, 495:119:10.

${ }^{23}$ Documents from the FRTS relating to the expulsions are found in AC, 534:7:455, 8-14. The expulsions were reported in Diario del Salvador, one of the main daily newspapers in San Salvador, on July 28,1929 , p. 1. Monterrosa's letter was first published in Diario del Salvador July 30, 1929, p. 1, and again in the same newspaper on August 21, 1929, p. 7.

${ }^{24}$ Diario del Salvador, August 14, 1929, p. 1.
} 
ful of urban idealists with no money and no ties to the peasant communities.

A police crackdown in November 1929 set the stage for a final showdown between the radicals and the reformers in the FRTS. The incident occurred in the city of Santa Tecla, just to the west of San Salvador, during a anti-imperialist demonstration organized by the Anti-Imperialist League. The FRTS was invited to participate in the march, but the delegation that arrived apparently was dominated by members of the Congress of Workers and Peasants. They handed out fliers on class conflict, one of which read: "It is not possible that we be always subjected to misery, suffering hunger, cold and nakedness, while the wealthy lead a princely life at the expense of our sweat and blood." 25 During their turn at the podium the delegates delivered speeches encouraging rural laborers to rise up against landowners. Police monitoring the event quickly broke up the demonstration, arrested six speakers and raided the local office of the FRTS. ${ }^{26}$

The police raid was a turning point in the history of the FRTS. Everyone in the union was incensed by it, but radicals and reformers proposed vastly different responses. The reformers suggested that a formal protest be lodged, but that the basic strategy of the union remain. The radicals countered that the raid was only the first of many to come and that the union must become more militant. The reformers controlled five of the seven seats on the Executive Council and rebuffed the radicals. ${ }^{27}$

It was at this moment that the radicals decided to wrest control of the union. They set their sights on the forthcoming election for a new executive council to be held in February 1930 at the VI Annual Congress.

It was at this crucial moment that the Comintern decided to play a more active role in El Salvador. It is not clear if this new interest was

\footnotetext{
${ }^{25}$ The leaflet is reprinted in Schott to Secretary of State, Nov. 25, 1929, United States National Archives (USNA), Records Group (RG) 59, 816.00/762. The events and the leaflets also are reported in Diario del Salvador, November 25, 1929.

${ }^{26}$ The PCS records make extensive reference to the events of November 1929. See AC, 495:119:7, 11; 495:119:10, 120 and 137; 495:119:11, 2-3; 495:119:12, 6-12; 495:119:13, 18 .

${ }^{27}$ According to a report from a Honduran agent of the Comintern who conducted an investigation in El Salvador, two members of the Executive Council were allied with the Congress. They were Aquilino Martínez, Treasurer, and Edmundo Amaya, Secretrary of the Interior. AC, 495:119:11, 2.
} 
sparked by developments in El Salvador, or by the Comintern's recent decision to make a greater investment in Latin America as a whole. ${ }^{28}$ In either case, shortly before or after the November police raid the Comintern sent at least three agents into El Salvador to assist the radicals. One agent was a Honduran of unknown identity. ${ }^{29}$ Another was Jorge Fernández Anaya, a Mexican, who went by his maternal name Anaya. The third was Jacobo Hurwitz, a Peruvian who was working alongside the Communist Party of Mexico (PCM) on behalf of the Peruvian APRA party. ${ }^{30}$ Anaya was by far the most influential. His organizational work in Mexico had earned him a position in the Comintern's new Caribbean Bureau. He was of Indian features, spoke Nahuatl and was able to travel in the countryside inconspicuously. ${ }^{31}$ Scholars have noted his presence in El Salvador, but they lacked the internal records to appreciate his prominent role. ${ }^{32}$ Anaya became the de facto leader of the radical faction and held an equally important position in the PCS after its formation. Records reveal that Anaya authored most of the party's major policy statements and played the lead role in teaching the rank and file about Marxism. His exhortations consumed the better part of each weekly meeting until he left El Salvador in late 1930.33

\footnotetext{
${ }^{28}$ At its Sixth Congress in1928, the Comintern announced the "discovery of Latin America." The Comintern considered Latin America to be useful as a front against United States imperialism. Caballero, Latin America, 24, and Chapter 5.

${ }^{29}$ The Honduran's report, in which he discusses his arrival and nationality, is found in AC, 495:119:11.

${ }^{30}$ Anaya describes his and Hurwitz' arrival in AC, 500:1:5, 18-21. See also 534:7:455, 23 for more discussion of Anaya's arrival. The best evidence we have into Hurwitz identity is an interview with Miguel Angel Vázquez, a Salvadoran who was a member of the Communist Party of Guatemala. He refers to Jacobo Hurwitz as a Peruvian who had founded a cell of APRA in Mexico as part of Haya de la Torre's initiative to build ties with the communist party in Mexico. See Taracena Arriola, Arturo, "Un salvadoreño en la historia de Guatemala," Memoria (Mexico City) 4:29 (enero-febrero, 1990), 93. Rodolfo Cerdas refers to a "Jacobo Hurwits" and a "Jacobo Jorowics." He describes the former as a Mexican who worked for the Comintern and had ties to Central America, but did not work in El Salvador, and the latter as a member of the APRA who arrived to El Salvador in 1930. See Cerdas, Communist International, pp. 60 and 98.

${ }^{31}$ From an interview with Anaya in 1990 by Carlos Figueroa Ibarra, "El 'bolchevique mexicano' de la centroamericana de los veinte," Memoria 4:31 (septiembre-octubre, 1990), 218.

${ }^{32}$ References to Anaya are found in Anderson, Matanza (1992 edition), pp. 42, 46, 59-61, and 92; and Cerdas, Communist International, pp. 98 and 103-5. There is also Anaya's own words in Jorge Anaya, "La fundación del Partido Comunista de El Salvador," Memoria 1:10 (mayo-junio, 1985): 232-240.

${ }^{33}$ Anaya's predominant role in the weekly meetings is evident from the notes of these weekly meetings found in AC, 495:119:7 and 495:119:8. For Anaya's participation in the authorship of major PCS documents at the VI Congress in May 1930, see the informe from the Congress in AC, 495:119:10.
} 
Under Anaya's guidance, the radicals went underground. They ceased public demonstrations and concentrated on gaining control of the FRTS. Anaya and a few other members of the radical faction traveled extensively throughout El Salvador in December 1929 and January 1930 to gain the support of union delegates who would be attending the VI Congress. Anaya described the campaign in one of his reports to the Comintern.

It was necessary to begin the formation of coteries in order to win over the young elements of the membership of the FRTS who were of revolutionary temperament and who might be determined to struggle for their class .... Under these conditions the Youth Communist League was organized, and received courses in trade-union activity and in the $\mathrm{ABC}$ of communism ....We began direct work with organizations ... of the FRTS; either sending delegates to the trade union organizations of the near-by villages at first and then later to all organizations; or giving written instructions on all the problems of our FRTS. In practice, in our daily work, we had completely nullified the traitorous leaders. ${ }^{34}$

By the opening of the VI Congress, the radicals had gained the needed votes and swept the reformers out of power. The seven seats of the executive council now belonged to Rafael Bondanza, Miguel Martínez, Carlos Castillo, Victor Angulo, Ismael Hernández, Petonilo Linares, and Miguel Mármol. ${ }^{35}$ At least two of these men, Hernández and Mármol, would go on to hold prominent positions in the PCS, while most of the others would be expelled in ensuing purges. The radicals also managed to expel Luís Felipe Recinos from the FRTS by the narrow margin of one vote. As a co-founder of the union and a leader of the reformist faction, his ousting signified the extent to which power in the union had changed hands and foreshadowed the debilitating hunt for reformists that was about to commence. Shortly after the VI Congress, the new leadership began purging suspected reformists. Anaya summarized the impact of this campaign in a report to the Caribbean Bureau: "During the months of February and March the organization weakened in numbers rapidly, principally owing to the fact that all the old elements became frightened at the growing combative character of the FRT[S]." 36

\footnotetext{
${ }^{34}$ F. Anaya to Buró del Caribe, April 9, 1931, AC, 500:1:5, 18.

${ }^{35}$ For a description of the meeting and vote see AC, 495:119:7, 11; 495:119:4, 16; 495:119:12, 6; $500: 1: 5,18$; and 534:7:455, 23. The names of the council members are found in a letter, perhaps from the Communist Party of Honduras, in San Pedro Sula, Honduras, to Sección Latino Americana of the Communist International, March 25, 1930, AC, 495:119:11, 3.

${ }^{36}$ Anaya to Buró del Caribe, April 9, 1931, AC, 500:1:5, 19.
} 
In March 1930, shortly after their victory at the VI Congress, Anaya and the radicals founded the PCS. Although they were comfortably in control of the FRTS, and had expelled many of its members, they believed the rank and file of the union still held too much sympathy for reformism. The PCS was to be a genuine radical alternative, a revolutionary vanguard, untainted by the bourgeois values, and a fellow combatant in the international war against capitalism.

For the first two months of its existence, the party busily recruited members and assembled the rudimentary elements of an administration. Party cells were established in San Salvador, Santa Tecla, Sonsonate, Ahuachapán and Santa Ana. The cell in San Salvador was the largest with roughly thirty members and was also the site of the Central Committee (CC). In total, the PCS had less than 100 members. All of this organizational work had to be done clandestinely because of police vigilance. ${ }^{37}$

At its first Congress in May 1930, the party outlined its objectives in a one hundred page, single-spaced manifesto, large portions of which were written by Anaya. The document is grounded in standard Comintern rhetoric: The party was to lead the masses in the revolutionary overthrow of the bourgeois government, replace it with a "dictatorship of the proletariat" and destroy capitalism in El Salvador. As the means to this end, the party adopted the same strategy as that of the Congress in 1929, organizing the coffee laborers in the west. The strategy was based on the idea that coffee was the foundation of capitalism in El Salvador and that coffee laborers would be the natural cause of its demise. The authors of the document made it clear that they held no illusions about an immediate victory, but as communists they were convinced that revolution was an inevitable stage in El Salvador's development. ${ }^{38}$

Despite its call for rural organizing, the PCS held highly ambivalent views about the countryside and its inhabitants. It acknowledged the centrality of the west, but it considered the "masses" who lived there to be insufficiently proletarian to support a socialist revolution. This

\footnotetext{
${ }^{37}$ A description of the structure and membership of the party during these earliest days is found in Anaya's report to the Buró del Caribe, April 9, 1931, AC, 500:1:5, 18.

${ }^{38}$ The specific discussion of the lack of an industrial proletariat and the need to organize the rural workers is discussed in the Informe del VI Congreso, May 1930, AC, 495:119:10, 125. A description of the Comintern's program for the "semi-colonial" nations of Latin America can be found in Cerdas, Communist International, Chapter one.
} 
ambiguity might reflect the influence of Moscow, specifically the strategic shift in the Comintern associated with the "Third Period" (19281934). Under the influence of Stalin, the Comintern took a hard turn to the left and shifted to a strategy of "class against class." Affiliated parties were expected to concentrate on uniting workers and rejecting non-proletarians. Small-holding peasants were suspect in this design, which in the case of Latin America was problematic because smallholding was so prominent, even in some agro-export sectors.

In his study of communism in Mexico, Barry Carr notes a similar uncertainly about the countryside on the part of the Mexican party (PCM). The urban cadres broke their ties to peasant leagues because they deemed the leadership of the leagues to be lacking in proletarian qualities. Carr attributes this to the influence of the Third Period. ${ }^{39}$

For an organization prone to interpreting society through a predetermined lens, the PCS had a very sober understanding of land tenure in western El Salvador. In its Tesis Agraria (Land Thesis) the party noted that the countryside was not simply a pool of proletarian labor, but consisted mostly of "small proprietors," i.e. peasants. Moreover, it acknowledged that most of these peasants had received title to their plots during the privatization of the communal lands in the 1880s and 1890 s. $^{40}$ Scholars of El Salvador came to appreciate this same information only within the last decade. They knew of the privatization process, but argued that it occurred rapidly and caused the virtual wholesale proletarianization of the countryside. Recent research by Aldo Lauria debunks this argument, showing that privatization was a lengthy process in which many of the former community members gained title. The result was a diversity of land tenure, small plots alongside large plantations, in which some peasants avoided full proletarianization. ${ }^{41}$ The fact that the PCS appreciated this reality in 1930 could have been a significant step towards devising an effective strategy for organization among the western masses. But it was not to be, for the party adhered to a rigid framework that denounced all forms of

\footnotetext{
${ }^{39}$ Carr, Barry, Marxism and Communism in Twentieth-Century Mexico (Lincoln: University of Nebraska Press, 1992), p. 29.

${ }^{40}$ The tesis agraria was written primarily by Anaya for the VI Congress of May 1930. AC, 495:119:10, 89.

${ }^{41}$ Aldo Lauria, "An Agrarian Republic: Production, Politics and the Peasantry in El Salvador, 1740-1920," Ph.D. Dissertation, University of Chicago, 1990. For a work that makes a similar case for Guatemala, see David McCreery, Rural Guatemala, 1760-1940 (Stanford: Stanford University Press, 1994).
} 
private property and identified smallholders as the enemy. A declaration from the May Congress reads: "This small proprietor is a smallbourgeoisie; an enemy of the class-based organization of workers; we cannot take them into our confidence. They simply are an exploiter of our class." 42 The consequence of this view was a failure to gain support among the peasants, who generally wanted more land or land of their own rather than the nationalization of private holdings. In hindsight, the party adopted a self-defeating strategy by identifying the west as the front line of revolution while identifying the people living there to be inherently counter-revolutionary.

\section{Party Debility}

Before the party could organize anyone in the west, it had to put its own affairs in order. Party leaders, Anaya in particular, placed great importance on the ideological outlook of their members. Not only did each of them have to be versed in Marxism, but they also had to loath anything that smacked of "reformism," "opportunism" or the bourgeoisie. In accordance with Comintern dictates, the party believed that the elimination of reformists took precedence over the destruction of capitalism because reformists could drain popular support away from the party. At the Congress of May 1930, the party referred to them as, "agents of capitalism, the bourgeois state and bourgeois political parties .... They try to trick the masses into believing that the current regime is just and good .... They are nothing other than the worst enemy of the working class." 43

It was within the context of this battle against reformism that the trade-union origins of the PCS assume importance. The party was born out of the battle against reformism in the FRTS and party leaders remained convinced that despite their best efforts the party was still infected with a bourgeois virus. Leaders suspected the rank and file, most of whom had been recruited from FRTS unions, and they suspected one another, for they too had cut their political teeth in the FRTS.

This unrelenting suspicion led to a "campaign of clarification," as one high-ranking member diplomatically labeled the ensuing witch

\footnotetext{
${ }^{42}$ Informe del VI Congreso, May 1930, AC, 495:119:10, 91. Page 119 offers a similar proclamation against small proprietors.

${ }^{43} \mathrm{Ibid}$., 15 and 57.
} 
hunt. ${ }^{44}$ One party declaration from the Congress of May 1930 reads, "The only available path for us to engage in is an irreconcilable class struggle [to] abolish all the bourgeois tendencies and prejudices in our organization and in our members." 45 Another document referred to the "need to fumigate our organization of the microbes, collaborationists, who deny the radicalization of the masses by virtue of associations with the bourgeoisie." 46 A member of the CC later defined this period as one of "liquidating the opportunist tendencies that existed in our movement at that time." 47 The campaign never matched the bloodletting purges in the Soviet Union, but it consumed the greater portion of the party's time and energy for the next year.

PCS leaders devised a two-fold strategy to eliminate reformism. First, members would be monitored for "bourgeois values," and then they would be subjected to an extensive educational program to train them in Marxist ideology and communist organizational tactics. However, a clear definition of "bourgeois values" was never provided. The most commonly offered version was the eerily vague, "conscious or unconscious betrayal of the working class." 48 When such ambiguity combined with ideological fervor, the result was a volatile mix hindered the party's entrance into the west.

Over the coming months, party members were sanctioned for a variety of behaviors, which, in the eyes of the leadership, demonstrated a lack of commitment to the communist cause. They were suspended for sleeping in, arriving late to, or skipping meetings. Other members were suspended for expressing a personal dislike for a fellow cadre. Numerous members were either suspended or expelled on the accusation of "associating with bourgeois political parties." One individual was suspended for accepting two colones to sign a manifesto in favor of a "bourgeois candidate for the presidency." Most of each weekly meeting was devoted to either investigating suspicious members or lecturing on ideology. While chastising members for their passive organizational work during one meeting, Anaya described the total commitment required of a communist: "One should not be nervous, for

\footnotetext{
${ }^{44}$ From testimony before an investigative committee of the Comintern in late 1932 to determine the events which transpired during the month of January 1932 in El Salvador; AC, 495:119:4, 16. See Section III below for a description of this investigation.

${ }^{45}$ Informe del VI Congreso, May 1930, AC, 495:119:10, 121.

${ }^{46}$ Ibid., 147.

${ }^{47}$ Testimony from Comintern investigation, AC, 495:19:4, 26.

${ }^{48}$ Informe del VI Congreso, May 1930, AC 495:119:10, 27 and 140.
} 
nervousness in the leadership will hinder the development of the organization, and for this reason it is necessary to understand that the combative revolutionary temperament consists of being a dynamic of revolutionary energy at the service of our class, with a cold head, capable of anything, that nothing can alter." 49

When one member named Flores spoke up to comment on the negative impact that sanctions were having on the party, he was expelled. In explaining the punishment, Luís Díaz, a high-ranking official, stated that Flores exhibited "oscillations" in his commitment to the party. ${ }^{50}$ Reprimand was not reserved for the rank and file; even the highest echelons were targeted. Luís Díaz, for instance, was expelled in November 1930 for "adopting a philosophical line contrary to that of the party." 51 All of the party's cells participated in the campaign against reformism, although the CC in San Salvador directed the process.

As late as February 1931, leaders still believed that reformism prevailed in the party. One leader lamented that "opportunism is still trying to orient our movement in support of the [government] party and its policies." 52 Not until the middle of 1931 did the party consider itself free to focus on the west.

When the party finally turned its attention to the countryside, it encountered myriad obstacles further hindering its ability to build ties to the masses. The party was effectively broke and organizers had to travel everywhere by foot. Party leaders berated the Comintern for failing to send more than $\$ 50$ each month, noting that other parties in the Caribbean received more. ${ }^{53}$ Meanwhile, surveillance and repression from the police and the military were increasing steadily. Orgar

\footnotetext{
${ }^{49}$ Ibid., 126.

${ }^{50}$ The process of expulsions and sanctions is found in the actas (nos. 7-11) of meetings of the PCS between November 18, 1930 and December 20, 1930. AC, 495:119:8, 1-9. The process against Flores is found in Informe del VI Congreso, May 1930, AC, 495:119:10, 35.

${ }^{51}$ The process against Díaz is found in the actas of the weekly meeting of November 12, 1930 , AC, 495:119:8, 5. Díaz was later reinstated after the charges against him were dismissed, AC, 495:119:8, 15.

52 Testimony from Comintern investigation, AC, 495:119:4, 24.

${ }^{53}$ The payments of $\$ 50$ are described in a letter from Buró del Caribe(?) to the Salvadoran section of the SRI, February 8, 1931. AC, 539:3:1060,2. The complaints regarding money, and the descriptions of traveling by foot are found in Hernández, to Secretario del Caribe, November 29, 1931, AC, 539:3:1060, 8-9 and 10-12. Further complaints regarding money are found in testimony from Comintern investigation, AC, 495:119:1, 14; a letter from the PCS to the Buró del Caribe, October 8, 1931, AC 495:119:7, 16; and Anaya's letter to Buró del Caribe, April 9, 1931, AC
} 
nizers commented repeatedly on the threat of incarceration or deportation. ${ }^{54}$ These hardships limited their ability to gain direct access to the masses, which was essential not only for building personal contacts, but also because the vast majority of the peasants were illiterate and could not read printed manifestos. One party member later declared before a Comintern committee that, "we had no direct channel to the masses ... almost never could we organize rallies." 55

The party's problems in the west were further complicated by the issue of ethnicity. Indians constituted a sizable majority in many western municipalities, whereas the party was comprised of urban ladinos. Recent research in birth records shows that in 1930 Indians made up ten percent of the total population of the nation. But in the three western departments of Sonsonate, Ahuachapán and La Libertad, the percentage was closer to forty, and in some municipalities, particularly those at the center of the 1932 revolt, it was almost one hundred. ${ }^{56}$ The traditional distrust between Indians and ladinos made the former suspicious of the latter bearing promises of political and economic salvation. Moreover, the atheism of communism conflicted sharply with the prominent role of the cofradias (religious brotherhoods) in Indians' lives.

Communist organizers also engaged in the potentially alienating project of supplanting or converting traditional Indian leaders, who typically had been chosen according to centuries-old cofradía customs. As one cadre put it, the party should be the sole representative for "all campaigns which deal with demands belonging to the working class." 57 While the PCS could do little about some of the intrinsic contradictions between itself and the western peasantry, it also had its own policies to blame. It opted not to devise a specific strategy to deal with ethnicity, choosing instead to ignore ethnic heterogeneity in favor of class ho-

500:1:5, 24. References to other countries receiving more money are found in testimony from Comintern investigation, AC, 495:119:4, 3-4.

${ }^{54}$ Lists of jailed comrades are provided in two letters from Hernández, PCS, to the Secretario del Caribe, November 29, 1931 and December 8, 1931, AC, 539:3:1060, 8-12; and in the informe from Anaya, August 12, 1930, AC 495:119:12, 6-7.

${ }^{55}$ The problem of illiteracy is discussed in testimony before the Comintern investigative committee, AC 495:119:4, 64. Descriptions of organizers' hardships are found in Hernández's letters, Ibid.

${ }^{56}$ Erik Ching and Virginia Tilley, "Indians, the Military and the Rebellion of 1932 in El Salvador," Journal of Latin American Studies 30:1, (February, 1998), 121-156.

57 Testimony from Comintern investigation, AC 495:119:4, 24. 
mogeneity. The result, as one member put it, was "a lack of work amongst the native Indians (indios nativos)." 58

Despite these serious limitations, the party did gain influence among some peasant communities through an astute organizational strategy. It focused only on grievances offered by the peasants themselves. Party leaders recognized that proselytizing about land nationalization, global revolution, or the establishment of a "dictatorship of the proletariat" was likely to erode rather than garner support. Party activists were told to educate the masses gradually: "to the masses it is necessary to explain things to them slowly, in various forms, many different times if necessary." 59

The most common grievance put forth by the peasants was the recent decrease in wages on the coffee plantations. The Great Depression caused the price of coffee to drop and growers responded in part by lowering wages. ${ }^{60}$ The PCS seized upon this opportunity and made wage increases the focus of its organizational attack. Cadres strategically arrived at the coffee plantations on payday. They also supported strikes organized by coffee workers and went on to lead a few of its own work stoppages. Most of these strikes were small affairs, but some were successful, in large part because the party made specific and attainable demands such as a nominal wage increase or better food rations. ${ }^{61}$ The party hoped that a series of minor victories would add up to something greater. During this period of active mobilization party membership grew to its largest size of over 400 . The principle cells,

\footnotetext{
${ }^{58}$ Informe de la sección de El Salvador, renido por el camarada Hernández de la junta del secreatariado del caribe del SRI, July 12, 1932, AC, 495:119:12, 25.

${ }^{59}$ Informe del VI Congreso, May 1930, AC 495:119:10, 140.

${ }^{60}$ Between 1929 and 1932, the value of Salvadoran coffee dropped from US $\$ 16.7$ per quintal to US $\$ 7.5$ per quintal. See Max Brannon, Breves consideraciones sobre la industria cafetalera en México y en El Salvador (San Salvador: Imprenta Nacional, 1934), p. 18. (A quintal is 46 kilograms.) Exports dropped accordingly from 120.4 million pounds in 1931 to 87.5 million pounds in 1932. See Victor Bulmer Thomas, The Political Economy of Central America Since 1920 (Cambridge: Cambridge University Press, 1988), p. 50. The drop in wages on the coffee plantations was noted by British foreign service officers in El Salvador, see Rodgers, San Salvador, to Sir John Simon, Foreign Office, January 7, 1932, Public Record Office (PRO), Foreign Office (FO) 371/15812, A612/918.

${ }^{61}$ Descriptions of the strikes are found in testimony from Comintern investigation, AC, 495: 119:4, 40-1 and 46. For the arrival of communists to the plantations on payday, see Administrador General for Concha G. v. de Regalado to Governor of Sonsonate, January 6, 1932, AGN, MG, SS, Box 2. Some of the strikes were described in the national press. For instance, a strike on the Sol plantation near Talnique, Department La Libertad, was described in Diario Latino, December 31, 1931, in the collection of press clippings in AGN, SI, Capitulo 1, Caja 17.
} 
however, were still centered in urban areas and the cell in San Salvador accounted for more than 75 percent of all members. Interestingly, the cell in Sonsonate was by far the smallest with only 18 members. ${ }^{62}$

\section{REBELLION}

Notwithstanding its organizational gains, the PCS ultimately failed in its aim to become the vanguard of the western masses. It recurrently had to confront its limited influence over the peasants, but two instances stand out. The first was the December municipal elections of 1931. The party considered such election to be "bourgeois" and boycotted them so that members could remain anonymous and concentrate on organizing. It was much to the party's chagrin to learn of the strong peasant support for the elections.

Mass involvement in the 1931 elections was made possible by a recent series of political reforms carried out by the administration of President Pío Romero Bosque (1927-1931). Reasons are still unclear as to why this long-time political insider became such a strong advocate for political reform, but shortly after assuming office Romero and handful of fellow administrators worked tirelessly to support genuinely democratic procedures. ${ }^{63}$ His successor, Arturo Araujo (March to December 1931) was a product of the reforms. Not surprisingly the PCS vilified both of these men, referring to Araujo as a "demagogic philanthropist," among other less savory things. ${ }^{64}$ By initially refusing to participate in the elections the party had underestimated the extent to which peasants identified local politics as a serious issue. Faced with the prospect of losing touch with its prospective mass base, the party ceded and joined the electoral fray. As a member of the CC later testified before a Comintern committee, "What choice did we have?" 65

The party presented a decidedly mild platform for these elections, choosing to focus on political rather than economic issues. The platform called for aid to children and the unemployed, but avoided reference to revolutionary, or even socialist ideas. Party leaders reasoned

\footnotetext{
${ }^{62}$ This figure is mentioned twice in testimony before the Comintern investigation, $\mathrm{AC}, 495$ : $119: 4,5$ and 55 .

${ }^{63}$ The reforms of the Romero presidency can be found in, Erik Ching, "From Clientelism to Militarism: The State, Politics and Authoritarianism in El Salvador, 1840-1940," Ph.D. Dissertation, University of California, Santa Barbara, 1997, Chapter 7.

${ }^{64}$ Informe del VI Congreso, May 1930, AC, 495:119:10, 117.

65 Testimony from Comintern investigation, AC 495:119:4, 47.
} 
that a platform laced with references to communist doctrine would only alienate the masses and serve to incite the forces of repression. ${ }^{66}$ The party had a degree of success in some urban areas, where its numbers were greatest. In San Salvador, for instance, the communist candidate ran a close third and received more than 1,400 votes. ${ }^{67}$ The party was able to make this strong showing in San Salvador because the new regime under General Martínez had made a de facto truce with the party in the urban areas. This "truce" generated substantial grist for the editorial mill as writers debated the wisdom of allowing communists to join in elections. ${ }^{68}$ But in the rural areas government repression continued unabated, forcing the party's to remain on the periphery of electoral mobilization. ${ }^{69}$

The second time the party confronted its inability to control the masses also came in the waning months of 1931, but this time with more serious consequences; the peasants wanted armed rebellion. Party organizers had been commenting on a rising tide of militancy in the rural areas. The Secretary General of the party informed the Caribbean Bureau in October that "these Comrades want to go from the Defensive to the Offensive ....We cannot deter the revolutionary wave ... the masses are thirsty for blood and gold ... these comrades are under the illusion that with their machetes they are sufficiently prepared to sustain a movement of this class." 70 In the words of a Comintern analyst, the PCS was facing a "genuine mass revolutionary movement of the peasants without a properly organized communist party." 71 An earlier report from a Comintern agent in El Salvador said

\footnotetext{
${ }^{66}$ The platform is discussed by a member of the $\mathrm{CC}$ in his testimony before the Comintern investigation, $\mathrm{AC}, 495: 119: 4,24-6$. Comintern analysts criticize the strategy at length, AC, 498: 119:1, 11-16.

${ }^{67}$ Diario Latino, January 5, 1932, p. 1, in collection of press clippings in AGN, SI, Capitulo 1, Caja 17. The election in San Salvador also was discussed by a member of the CC in testimony from Comintern investigation, AC, 495:119:4, 44.

${ }^{68}$ The issue of the new Martínez government allowing the PCS to participate in the election is discussed in Diario Latino, December 12, 1931; Patria, December 21, 1931; and Diario Latino, December 22, 1931. All of these are found in the collection of press clippings in AGN, SI, Capitulo 1, Caja 17.

${ }^{69}$ The most visible influence of the party to the elections was the nomenclature of some political parties. A pair of examples are the "Partido Sindicalista de Trabajadores" in Juayúa and the "Sindicato de Trabajadores del Campo" in Izalco. See Emelio Redaelli, Alcalde of Juayúa, to Governor of Sonsonate Department, December 18, 1931, AGN, MG, SS, Box 3; and telegram from Valdez, Alcalde of Izalco, to Governor of Sonsonate Department, December 15, 1931, AGN, MG, SS, Box 1.

${ }^{70}$ Report to Buró del Caribe from PCS, October 8, 1931, AC, 495:119:7, 16.

${ }^{71}$ Testimony from the Comintern investigation, AC, 495:119:1, 5.
} 
that, "the fact is that the campesinos ... demonstrate combative tendencies, desiring to go to battle with their machetes in hand."72

The party, with the exception of a small minority of its members, firmly opposed the idea of armed rebellion. Party leaders were convinced that the proper conditions for revolution did not yet exist in $\mathrm{El}$ Salvador. Anaya had written in September 1930 that "at this time we cannot consider that truly revolutionary conditions exist; that which exists is a rapidly growing crisis that will result in a truly revolutionary situation." 73 The party did not waver from this line after Anaya's departure. Party leaders realized that their rank and file lacked experience, the masses did not share their ideological outlook, and most importantly, neither the party or the masses possessed the necessary weaponry to engage the Salvadoran military.

Interestingly, the small faction that supported the idea of armed rebellion appears to have been led by the famed Salvadoran activist Farabundo Martí, who is often cast by scholars and laypersons alike as a central figure in the PCS and the rebellion. Martí indeed was an activist of renowned and even legendary stature, from his tenure as Sandino's secretary in Nicaragua to his repeated jailings in, and deportations from El Salvador in 1931. But party records show that Martí was estranged from the PCS. His official status in El Salvador was as a representative of the Comintern's international aid organization, the Socorro Rojo Internacional (SRI). While he made recommendations to the party and occasionally participated in its planning sessions, party leaders seldom looked to him. The party still bore Anaya's influence, and after he left El Salvador, persons loyal to him retained control of the party and defended his legacy.

Party documents reveal that Anaya and Martí were at odds with one another. The cause of their conflict is unknown, but whatever the case, Anaya criticized Martí in his reports to the Comintern and continued to speak negatively about him for the rest of his life. He considered Martí to be impulsive and lacking in discipline. Martí fared no better with the leaders of the PCS after Anaya's departure. They sharply criticized his willingness to bypass party hierarchy, especially in August

\footnotetext{
72 This quote comes from a report made by PCS to Buró del Caribe (no date, but context suggests sometime late in 1930), AC, 495:119:11, 16.

${ }^{73}$ Informe from Anaya, October 12, 1930, AC, 495:119:12, 16.
} 
1931 when he met with President Araujo without permission or instructions from the party. ${ }^{74}$

This conflict between Martí and the main leadership of the PCS suggests the possibility that Martí was organizing the peasantry apart from the party. Unfortunately, there is no evidence to determine if this indeed happened. But logic dictates that if Martí was trying to organize the peasantry, his impact was limited. $\mathrm{He}$ and his supporters would have started at the same late date as the party, and they too were few in number. Moreover, Martí spent most of the year 1931 either eluding police, sitting in jail, or trying to return to El Salvador after having been deported. ${ }^{75}$ It is also logical to assume that PCS activists would have been aware of significant inroads within the peasantry on the part of a rogue faction, and would have commented on it as an explicit threat to the party. In spite of the highly public nature of some of Martí's activities, particularly his incarceration and hunger strike in May 1931, to credit the rebellion to him or his faction would be to commit the same error as attributing it to the PCS. ${ }^{76}$

Ironically Martís status in the party increased significantly after his death and the virtual destruction of the party in 1932. Martís supporters survived the matanza more intact than did Anaya's, so it was they who oversaw the reorganization of the party in the mid-1930s. One of the first documents they put forth was a lengthy analysis of the 1932 rebellion that blamed Anaya for the failures and hailed Martí as the party's proper role model. ${ }^{77}$

Despite the party's opposition to armed insurrection, elements of the western peasantry were determined to rebel. As one of the members of the $\mathrm{CC}$ who survived the matanza later commented, "thé masses were tired of being beaten up and they wanted to take the

\footnotetext{
${ }^{74}$ Anaya's criticism of Martí are located in a report from Anaya to Alberto Moreau, Sect. General of the Colonial Department of the PCUSA, AC 495:119:12, 8; and in his interview in Figueroa, "El bolchevique." The party's criticism of Martí for meeting with Araujo is found in testimony from Comintern investigation, AC, 495:119:4, 37.

${ }^{75}$ Jorge Arias provides a good narrative of Marti's life, including the events in 1931, in Farabundo Martí. There is a letter from Martí to the Communist Party of Costa Rica from onboard the ship that was carrying him into exile in Costa Rica in AC, 495:114:2, 3. His exiles to and returns from Guatemala in August 1931 are described in testimony from Comintern investigation, AC 495:119:4, 37.

${ }^{76}$ Martí's arrest in April and his May hunger strike are described in the informe of July 12, 1932, AC 495:119:12, 26 and 27

${ }^{77}$ Informe rendido por los camaradas de El Salvador, September, 1936, AC 534:7:455, 23-28.
} 
battle to a higher level." 78 Contemporary reports coming out of El Salvador indicate that military repression against the western peasantry was inded on the rise in the final weeks of 1931 . The British Minister, for instance, reported that a "good source" informed him that the National Guard had killed sixty striking workers on a western finca. ${ }^{79}$ The U.S. Chargé wrote about another incident in which the National Guard broke up a strike on a plantation near Saragosa in $\mathrm{La}$ Libertad Department, killed fourteen workers, wounded another fifteen and dumped the bodies into a ditch. ${ }^{80}$ The Governor of Sonsonate Department commented on the growing militancy of the peasantry, but he reasoned that "[it is] improperly called Communism; in reality it' is open opposition by the proletariat against [local] power for reasons of their miserable situation made worse by the economic crisis." 81

What was the party to do, support a doomed rebellion, or watch passively as the masses engaged the class enemy alone? Party leaders found this to be a series dilemma, as the Secretary General revealed in one of his reports, "the conditions in which we find ourselves are insuperable." 82 To discover how the party answered this question, we turn to a documentary source of unprecedented richness, the transcripts of an investigative committee organized by the Comintern in late 1932. In the six weeks prior to the rebellion the party isolated itself from the Comintern, sending only two brief messages. The first was a four-line note stating that the party had decided "to fight for power." 83 The second was a desperate plea for money and weapons. ${ }^{84}$ The Comintern sent numerous letters, all of which went unanswered. It even sent two operatives from Mexico to reestablish contact, but the PCS rejected them on the grounds that they lacked proper credentials..$^{85}$ The investigative committee was the Comintern's attempt to learn what had transpired during the lapse of communication. The two principle witnesses were Comrade " $\mathrm{H}$ " and Comrade "Marochi," members of the $\mathrm{CC}$ who had survived the matanza and escaped from $\mathrm{El}$ Salvador.

\footnotetext{
${ }^{78}$ Testimony from Comintern investigation, AC, 495:119:1, 19.

${ }^{79}$ Rodgers to Sir John Simon, Foreign Office, January 7, 1932, PRO, FO 371/15812, A612/918.

${ }^{80}$ Finley to Secretary of State, October 3, 1931, USNA, RG 59, 816.00B/42, Box 5507, Folder no. 1 .

${ }^{81}$ Governor of Sonsonate to Minister of War, November 23, 1931, AGN, MG, SS, Box 4.

${ }^{82}$ Report from PCS to Buró del Caribe, October 8, 1931, AC, 495:119:7, 16.

${ }^{83}$ Testimony from Comintern investigation, AC, 495:119:1, 4.

${ }^{84}$ Ibid., 32.

8.5 Ibid., 5.
} 
The transcripts of the investigation reveal that party members did not know how to respond to the impending revolt. Confusion reigned in the party's meetings and the CC itself was divided. Some members insisted that participation in the rebellion was ludicrous, while others argued that the revolt was inevitable and that the party had no choice but to join. Finally, on January 10th, just ten days prior to the outbreak of revolt, the $\mathrm{CC}$ decided to join. Regarding the decision, Comrade $\mathrm{H}$ testified that "the masses were very anxious to liberate themselves, and the Communist Party [was] weak ... and [let itself be] carried away by the impulse of the masses .... There was not a single comrade who could foresee the repercussions of the events ....We estimated good things. We were mistaken, and the most militant of our movement paid with their lives ....We did the best we could ... what was done was necessary to do." 86

As the day for revolt drew near, the upper echelons of the PCS grew increasingly divided. Comrade Marochi proposed the rebellion be postponed, but his opponents on the $\mathrm{CC}$ held the majority and voted six to three to proceed. Marochi offered his opinion of the vote: "So many of our comrades were in jail in almost every city of the country, more arrests were being made and it was clear that all our comrades were to be shot and they [the supporters of the revolt] thought it would be better that all of us should share the same destiny. None of them showed any logic or clear analysis, [nor could they explain] why this action was justified." 87 Despite his opposition to the decision, Marochi recognized it as irrelevant, for the party could not have stopped the rebellion anyway: "If the insurrection had, for one reason or another, been postponed by the $\mathrm{CC}$, the impulse of the masses was for struggle, and this [was the case] from the very beginning, such that at any rate, this [uprising] could only end as it did." 88

In the final days leading up to the revolt the party employed the few resources at its disposal to influence its direction. The evidence is sketchy as to precisely what was done, but it seems the party directed its main efforts at coordination. The rebellion appears to have been a conglomeration of uprisings by distinct communities, probably in contact with one another, striking at local power. The PCS apparently used what influence it had to convince the communities to synchronize

\footnotetext{
${ }^{86}$ Ibid., 1; and 495:119:4, 2.

${ }^{87}$ Testimony from Comintern investigation, AC, 495:119:4, 59.

${ }^{88}$ Ibid., 67.
} 
their attacks and create the illusion of a single massive revolt. Marochi testified that immediately after the CC voted to join the rebellion on the 10th of January, it sent messengers from San Salvador to the west carrying instructions. ${ }^{89}$ Miguel Mármol's memoir also refers to "taking the plan to the masses," and "dispersing [from the meeting of 10 January] to communicate the proposal to the immediate leadership in the areas of operation to which we had been assigned."90 The recipients of these instructions were so-called Red Commanders, resident communist organizers or local persons in the confidence of the party. ${ }^{91}$

The party also called upon its sympathizers in the army. The PCS had been recruiting in the army for the past six months. Most soldiers were young conscripts from the countryside and the party considered them to be ideal prospects for conversion to its communist cause. Party leaders reported that its recruitment efforts had garnered rewards, but they did not mention the identity or number of converts. It appears that a number of the soldiers heeded the party's call to turn their weapons on their fellow soldiers. Marochi testified that "those soldiers with whom we had contact participated in the events." They were vastly outnumbered and were flushed out and either shot or jailed. ${ }^{92}$

The presiding officials of the investigative committee concluded that the PCS had erred in joining the rebellion. As one committee member put it: "I say the analysis made by the CC on January 10th was a very incomplete and incorrect one and, therefore, led to a decision which was wrong." 93 The member then summarized the party's weaknesses: "The party was very small, a couple hundred people, and poorly organized, very insufficiently in the strategic section of [the] Salvadoran economy. A Party which had a weak leadership, untrained in the application of Leninist methods of strategic organization of the masses. No organized peasant movement worth mentioning, and not a very strong revolutionary mass organization .... The $\mathrm{CC}$, as such, was practically out of commission during the uprising. [There was] no $\mathrm{CC}$ to lead the masses ... no central leadership, no national leadership, just

\footnotetext{
${ }^{89}$ The sending of these instructions is mentioned by Marochi in his testimony before Comintern investigation, AC, 495:119:4, 47-9. They also are referred to in another testimony in AC, 495:119:1, 13.

${ }^{90}$ Dalton, Miguel Marmol, 342.

${ }^{91}$ The Red Commanders are discussed in testimony from Comintern investigation, AC, 495: 119:1, 21.

${ }^{92}$ Ibid., 495:119:4, 52 and 65; and 495:119:1, 22.

${ }^{93}$ Ibid., 495:119:1, 20.
} 
a series of local insurrections." 94 But when the member then advised Comrades $\mathrm{H}$ and Marochi on what should have been done, the recommendation was so vague that it offered no practical alternative: "In my opinion this is what the CC should have decided at its Plenum of Jan. 10. Not to begin the preparations for an armed struggle for power but to begin a systematic unfolding of the widest mass struggles for the immediate, political, economic and other demands as I have mentioned before, organizing revolutionary organizations in this process, showing the masses the way out, and preparing the Party in those localities where armed struggle seemed to be almost inevitable to place [itself] at [the] head of those struggles and lead them in accordance with these demands and for these demands." 95

\section{NAHUizalco: Elections and INSURRECTION}

In the absence of a communist directing role, we are left with abundant questions. How was the 1932 rebellion organized? What motivated its participants? Did messianism play a role? Was it a jacquerie, a spontaneous explosion of pent up anger brought on by factors only partially understood by the rebels themselves? In seeking answers to these questions, we confront profound lacunae in the sources. Indians and peasants, whether as communities or individuals, seldom left behind records, in part because the government did not investigate the rebellion but quashed it with massive violence. A member of the Comintern's investigative committee struck an appropriate tone in 1932 in noting that, "it is impossible to deal at present with the lessons of the uprising itself ... because we know practically nothing of how the uprising developed in [the] various localities." ${ }^{96}$ But valuable evidence can be gleaned from archival materials in El Salvador, particularly documents relating to elections and political disputes in the village of Nahuizalco, a focal point of both the rebellion and the matanza. The evidence reveals that the Indian community in Nahuizalco had a long history of autonomous organization and competed with local ladinos for control over municipal government. Not coincidentally, the rebellion erupted at the same time that this ongoing conflict reached a peak. ${ }^{97}$

\footnotetext{
94 Ibid., 19 and 21.

${ }^{95}$ Ibid., 20.

${ }^{96}$ Ibid., 22.

${ }^{97}$ For an alternative view of Nahuizalco case based partly on some of the same sourcs, see Alvarenga, "Reshaping," and Cultura y ética.
} 
Nahuizalco is located northwest of Sonsonate City at the base of the coffee highlands between Sonsonate and Ahuachapán Departments. The village has pre-Colombian origins and has long been recognized as a center of Indian culture. Recent research in the village's birth records shows its population to have been nearly 90 percent Indian in the first half of the twentieth century. ${ }^{98}$ It was also a sizable village, with more than 15,000 inhabitants in 1930, accounting for more than ten percent of Sonsonate Department's total population. Evidence on land tenure reveals a predominance of communal-based smallholding in the village. Census records from 1858 classified nearly 100 percent of the males in the village as "jornaleros," which in the parlance of the day meant peasant agriculturist. The privatization decrees in the 1880s and 1890 s adversely affected smallholding in the village, but like their counterparts in other regions, the peasants of Nahuizalco titled much of their former communal lands such that smallholding continued to prevail. A few ladino-owned plantations did emerge nonetheless. A government survey of the village in 1913 refers to the new ladino landowners and the Indians who worked for them. But the survey also noted the continuation of smallholding: "one of the circumstances that most contributes to the development and well-being of this district is the manner in which the rural property is divided up; here each inhabitant possesses a piece of land where he grows his subsistence crops." This conglomeration of evidence shows Nahuizalco to have been inhabited by Indians who retained a substantial economic presence despite the privatization decrees and the economic ascent of ladinos..$^{99}$

Rarely were Indians in El Salvador able to hold municipal office or compete with ladinos for control over municipal government, even when they held a majority of the population. Racism and ethnic preju-

\footnotetext{
98 Ching and Tilley, "Indians, the Military."

${ }^{99}$ Population figures from 1930 are found in the 1930 census, Población de la República de El Salvador (San Salvador: Imprenta Nacional, 1930). Nahuizalco's population grew from 5,000 in 1858, to 9,000 in 1900 , and to 14,000 in 1913. See López, Lorenzo, Estadística general de la República de El Salvador (San Salvador: Ministerio de Educación, 1974 [1858]), 160-2. For population figures from 1900 see Informe, Governor of Sonsonate Department, January 12, 1903, AGN, MG, unclassified box. For the privatization of the communal land and the predominance of small holding see Lauria, "Agrarian Republic," 234-61, and 391-403. For the lists of fincas and their ladino owners see Directorio comercial, pp. 494-6. The 1913 survey is from Cerridos, Sonsonate City, to Minister of Government, September 20, 1913, AGN, MG, SS, Box 5. A 1934 survey shows substantial smallholding in corn and bean production and lists the agriculturists by name, most of whom bear typically Indian surnames. See the survey dated July 13, 1934 in AGN, MG, SS, Box 3.
} 
dice played their part in this separation, as did the legacy of the Spanish-era's division of society into a república de los indios and a república de los españoles. After independence, Indian communities in $\mathrm{El}$ Salvador were under the dictates of national law along with ladinos, but they retained a degree of autonomy over their communities. Ladinos expected them to accept the limits of their domain and remain subject to the formal government without harboring expectations of participating in it. On rare occasions, however, Indians crossed their boundaries. Nahuizalco is one of the few cases in which Indians competed directly with ladinos for local government.

Archival evidence relating to Indian political activity in Nahuizalco opens in the year 1884 with a rebellion. On the night of 5 October as many as 2,000 Indians attacked the town, killed the municipal officials and burned the municipal hall, the archives and the home of a local ladino who was known as the "greatest oppressor" of the Indians. The rebels killed more than two dozen people, all of them ladino. After suppressing the revolt and returning the ladinos to power, the government launched an investigation and eventually executed ten suspected ringleaders. ${ }^{100}$ The importance of this rebellion is twofold. It demonstrates conflict along ethnic lines, and it reveals that as of 1884 ladinos controlled them municipal council. Just one year later, in the election of 1885 , Indians gained the council and held it for the next 18 years.

The Indians came to power in 1885 probably as a result of the overthrow of President Rafael Zaldívar (1876-1885) in May of that year. The coup was led by General Menéndez, who was aided by a number of other generals, including General Rafael Gutiérrez, who according to reports from the U.S. Consul, commanded a force of Indian recruits from Nahuizalco. ${ }^{101}$ Nahuizalqueños probably had served in the military on prior occasions because witnesses to the 1884 rebellion testified that some rebels were wearing militia uniforms. ${ }^{102}$ It is likely that the Indians received political control in their municipality in exchange for their service to the coup.

\footnotetext{
${ }^{100}$ The description is taken from Lauria, "Agrarian Republic," 514-9, whose evidence derives from the records of the official investigation of the rebellion. The rebellion is also described in the 1913 survey from Cerridos, Sonsonate City, to Minister of Government, September 20, 1913, AGN, MG, SS, Box 5.

${ }^{101}$ Cardenal, poder eclesiástico, 127.

${ }^{102}$ The issue of rebels in militia uniforms is drawn from Lauria, "Agrarian Republic," 514-9, and also from discussions with Lauria who described the contents of the evidence in greater detail. I would like to thank Aldo for sharing his information.
} 
Regardless of the circumstances, an Indian by the name of Nicolas Lúe became Alcalde in December 18,85. Indian surnames such as Lúe, Tepas, Lipe, Cumil, Nolasco and Córtez dominate the lists of municipal officials over the next 18 years. ${ }^{103}$ A pair of nullification requests from 1887 and 1894 suggest that the Indians were divided into at least two political factions because both requests were submitted by Indians in denunciation of other Indians. ${ }^{104} \mathrm{~A}$ lack of corroborating materials prevents the reconstruction of these rival networks. Nonetheless, it is clear that Indians were in command.

Ladinos kept a low profile throughout the first decade of Indian rule. But in the election of 1896, they ended their respite. They were led by the Brito family, and particularly Eduardo Brito, the family patriarch, an aspiring cattle rancher who eventually acquired two sizable fincas in the Nahuizalco region. The Britos were allied with another ladino family, Valdés, whose principal representative was Sebastián, owner of the finca "Santa Teresa." The Valdés family would also become a prominent landowning clan, eventually possessing five fincas around Nahuizalco. ${ }^{105}$

In the election of 1896 this ladino alliance requested the national government nullify the Indian victory. A local citizen described the conflict in plain terms, although his sympathies lay with the Indians:

During last Sunday's elections for local authorities in this village, some ladinos attempted to elect as Alcalde Sebastián Valdés; but the people, that is the Indians, rejected said individual and instead chose the Indian José María Tepas as Alcalde and other Indians for the remaining posts. Those persons who supported the candidacy of Valdés are dissatisfied and are working to nullify the elections contrary to the will of the people. ${ }^{106}$

The ladinos failed to find allies in the national government because the President at that time was General Gutiérrez, who had led Nahuizalco's Indians in 1885.

The ladinos failed in a second grab for power in 1901, but then

\footnotetext{
${ }^{103}$ Appendix 3.2 in Ching, "From Clientelism."

104 Junta de Elección, Nahuizalco, 1887, AGN, MG, SS, Box Política 1890-1899, 1900-1908"; Nulo, 1894, AGN, CN, Box 1.

${ }^{105}$ The landholdings of the Brito and Valdéz families are found in Lista de Agricultores Principales, Nahuizalco, March 8, 1912, AGN, MG, SS, Box 3; and Directorio comercial, 494-6. ${ }^{106}$ Juan Aviles, Nahuizalco, to Minister of Government, December 23, 1896, AGN, MG, 1896, Box 5.
} 
succeeded two years later in the election of 1903 . They won the contest by seizing the polling station and making Eduardo Brito President of the Directorio, the electoral commission in charge of voting. Another member of the Valdés family, Arcadio, was elected Alcalde. It is possible that the ladinos allied themselves with an Indian faction, for the other seven members of the council (Martín Hernández, Eulalio Guzmán, Ambrocio Pérez, Andrés Mauricio, Pedro Crúz, Eulalio Tadeo, and José Zacapa) bear surnames common to Indians of the region. Unfortunately none of the names appear in corroborating documents which might allow ethnicity or political loyalties to be traced. Certainly none of them were from known ladino families. If this was an example of an inter-ethnic alliance, it appears to have been an isolated instance, for in the ensuing elections competition ran strictly along ethnic lines.

The result of the next election is not known, but in 1905 the ladinos won again. Members of the Valdés and Brito families controlled the Directorio and Sebastián Valdés was elected Alcalde. ${ }^{107}$ Results of the next eighteen elections are not known, but it appears that Indians managed some victories. For instance, a local observer commented that Indians "almost always are in control of this Municipality." $108 \mathrm{We}$ know for sure that Indians won a highly contentious election in 1923. The ladinos were now led by Rodolfo Brito, heir to Eduardo's political empire, and Antonio Contreras, his nephew. The two of them convinced members of a nearby National Guard post to prevent Indians from entering the polling place and ensure that Contreras was elected Alcalde. ${ }^{109}$ But the Indians managed to nullify Contreras's victory. Thereafter, the Indian and ladino factions constantly jockeyed for political position and threw one another out of office. A document from September 1926 reveals that the Alcalde was an Indian by the name of Pedro Rodríguez, but a letter dated five months earlier reveals that Brito and Contreras were in power. ${ }^{110}$

\footnotetext{
${ }^{107}$ Junta de Elección, Nahuizalco, December 14, 1903, AGN, MG, SS, Box "Política, 18901899, 1900-1908."

${ }^{108}$ Minister of Government to Governor of Sonsonate Department, April 26, 1926, AGN, MG, 1926, Box 2.

${ }^{109}$ Juan Aviles to Minister of Government, December 23, 1896, AGN, MG, 1896, Box 5; see also Nullification, Nahuizalco, December 14, 1923, AGN, CN, Box 5; and the Lista de electos, Sonsonate Department, from Departmental Governor of Sonsonate to Minister of Government, December 13, 1923, AGN, MG, 1923, Box 4.

${ }^{110}$ The reference to Rodríguez is found in a note from the Governor of Sonsonate Department to the Minister of Government, September 9, 1926, AGN, MG, 1926, Box 6. The letter in question is from the three ladinos (Leonidas Durán, Manuel González and Alfredo Alvarado) and is
} 
With the arrival of Pío Romero Bosque to the presidency in 1927, Indians had an opportunity to regain control of the municipal council once and for all. With Romero's emphasis on democratic procedures, and by virtue of their overwhelming majority, the Indians should have had a great advantage. Indeed, they won the election of December 1927, but the Brito clique demanded the election be annulled because the Indian victor, Pedro Mendoza, was illiterate and thus unqualified for office. The Romero government investigated and eventually ruled in Brito's favor, despite the advice of the Comandante of Sonsonate Department who wrote that, "it is better to have four thousand content Indians rather than four content ladinos, who have used the municipal offices only to swindle the Indians."'111

For the next four years Nahuizalco became a hotbed of ethnic political conflict. The group in power was harangued constantly by the other's denunciations and nullification requests. ${ }^{112}$ One of Brito's requests from 1930 charged Pedro Mendoza, then serving on the municipal council-apparently despite his illiteracy-with drunkenness, another accusation that could disqualify him from holding office. Mendoza countered that Brito's request was "motivated by nothing more than bitterness over their loss in the last election." 113 The government ruled against Mendoza.

The hopes offered by the Romero reforms were dashed against the reality of power relations in Nahuizalco. Except for one instance in 1929 , Indians failed to regain control of the municipal government after their initial success in 1927. The ladinos were powerful beyond their numbers, possessing significant financial resources and controlling the municipal police. The ladinos also had some other elements in their favor. The Romero government, while supportive of democratic

transcribed in a note from the Minister of Government to Governor of Sonsonate Department, April 26, 1926, AGN, MG, 1926, Box 2. The letter stated that Antonio Contreras had been made Alcalde and Rodolfo Brito had been appointed as judge and reads, "as Judge he engages in every class of abuse and venality; he is a heavy burden upon the poor and Indian peoples." The letter also claimed that Contreras and Brito insured that only their friends and family members were appointed to the police force.

${ }^{111}$ Nulo, December, 1927 Nahuizalco, AGN, CN, Box 5. Also cited by Alvarenga, "Reshaping Ethics," 338.

${ }^{112}$ For example, between December, 1929 and January, 1932, five nullification requests originated from Nahuizalco. The respective dates are, December, 1929; August, 1930, September, 1930; December, 1930; and January, 1932. See AGN, CN, Boxes 7 and 9.

${ }^{113}$ Request for nullification of Pedro Mendoza as Regidor, September 9, 1930, Nahuizalco, AGN, CN, Box 7. 
ideals, was far removed from the local complexities of Nahuizalco. Government authorities were easy prey, and probably harbored the same stereotypical attitudes about Indians that Nahuizalco's ladinos provided in their denunciations. Such influence probably made it easier to believe that Mendoza was a drunk, whether or not he drank. The Romero government was also overwhelmed by a multitude of nullifications pouring in from across the country. Government officials did not have the time to conduct proper investigations, and in a pinch they found it easier to preserve the status quo, which in Nahuizalco after 1926 meant favoring ladinos. In one notable exception the government's lack of knowledge actually worked to the advantage of the Indians. In the election of December 1929, the ladinos won the initial election, but in an ironic twist the Indians charged the victor, Rodolfo Brito, with drunkenness and demanded nullification. In response, the Government dispatched the Deputy Departmental Governor who was so busy with a backlog of cases that he abandoned all pretense of discovering Brito's actual condition. He ruled in favor of the Indians simply because "they presented more witnesses than the opposition." 114 This odd form of democracy seldom benefited the Indians. By the municipal election of January 1932, they ran out of patience.

The municipal elections that took place in January 1932 had been postponed from their original date in December 1931 because of political events at the national level, notably the coup that brought General Martínez to power. The timing was inauspicious, for throughout the western region Indian and peasant communities were mobilizing for insurrection and the day of the election coincided almost exactly with the planned day of the revolt. The ladino slate in the election was led by Francisco Brito while the Indian slate was headed by Pablo Cruz. When it came time to vote, the ladinos seized control of the electoral hall and allowed Indians to enter but recorded their votes in favor of Brito. The Indians demanded nullification. They sent their first request to the Governor of Sonsonate on January 16th. The Indians knew that nullifications normally required two months to be processed, and decisions seldom arrived in less than four months, but they wanted immediate action. Four days later, on January 20th, they sent another letter to Sonsonate. A third petition was sent the following day. It stated that failure to act would have grave consequences: "Certainly it was not your intention to forget our petition, nor is it

${ }^{114}$ Nullifcation request for December, 1929 municipal elections, Nahuizalco, AGN, CN, Box 7. 
normally obligatory to respond in such short time, but failure to transmit even a verbal acknowledgment of our petition is now a threat to the social order." 115 No response came and on the next day Nahuizalco was overrun by armed peasants.

A nugget of evidence from Izalco suggests that Indians were actively involved in the political process in that region as well. Following the election of December 1929, Feliciano Ama, a leader of one of Izalco's two Indian communities, sent the government a nullification request accusing the recently-victorious ladino candidates of electoral improprieties. The government rejected the request. Ama turned out to be a main instigator in the 1932 uprising and was executed by hanging during the matanza. ${ }^{116}$

The evidence from Nahuizalco is fragmented but highly suggestive. While it does not identify the insurgents or the specifics of the rebellion, it does reveal a long history of intense political conflict between Indians and ladinos that came to a head in January 1932. The Indians' obvious impatience in their final nullification request confirms the rapid pace at which events were unfolding. This evidence, combined with our prior knowledge about the economic decline and wage reductions caused by the Great Depression offers compelling possibilities for both the immediate and long-term causes of the rebellion. At the very least, the evidence reveals autonomous mobilization on the part of the Indians and their capacity to identify political goals and pursue them relentlessly. An outsider wanting to build ties with the Indian community of Nahuizalco would have needed a detailed, nuanced understanding of the structure and function of Indian society and knowledge of its history of political activity. By all accounts, these are precisely what the PCS lacked.

\section{CONCLUSION}

Our conceptualization of the rebellion of 1932 draws comparison to another Indian uprising, that of the Algonquian people against the British in the Ohio River Valley in 1763. Scholars of that event searched for a leader, someone whom they could cast as both agent provocateur and symbol of all the rebels' aspirations. They focused on the Indian named Pontiac. Recent research suggests that perspective

\footnotetext{
${ }^{115}$ Nullification request for January, 1932 municipal elections, Nahuizalco, AGN, CN, Box 9.

${ }^{116}$ Nullification request for December 1929 municipal election, Izalco, AGN, CN, Box 7.
} 
betrays the complexity of the event. The uprising was not a single rebellion, centrally inspired and individually directed, but "a group of separate and loosely linked rebellions" by disparate villages spread out along the Ohio River. The similarities to the rebellion of 1932 are obvious, except that scholars looked to an organization rather than an individual. ${ }^{117}$

The rapid unfolding of events in El Salvador in January 1932 forced many people to make difficult and potentially life-threatening decisions. The members of the PCS had to decide not only what was best for their organization, but also whether they as individuals were prepared to translate rhetoric into reality, especially for a cause that many of them considered doomed. Notwithstanding the personal fortitude it took to join the rebellion, the members of the PCS were peripheral actors. With less than six months of spotty organization in the western countryside, they had built few lasting ties with the peasants. Instead, the rebellion was inspired and organized by residents in the west, and although the evidence is limited, it appears that ethnically-based conflict over municipal government was a driving force. A primary cause of the party's limited organizational success in the west was the contradictions between its ideology and the social realities of the countryside. The party rejected smallholding and ignored Indians, while the masses of the western region were predominantly Indian peasants.

When viewed alongside other communist movements in early twentieth-century Middle America, the PCS's failure to establish lasting ties with the countryside was not universal. In Mexico, for instance, the PCM worked diligently in the Laguna region in the mid-1930s and forged, according to Barry Carr, a "worker-peasant" alliance. ${ }^{118}$ Cuba, offers a counter example. The Cuban Communist Party (PCC) had an uneven presence in the rural sugar-growing regions in the center and east of the country. This was particularly apparent during the rapid mobilization in the summer of 1933 when sugar workers occupied several dozen mills and estates. Communist slogans and organizers were present during the occupations, but local leaders often surpassed party cadres in directing the course of events. ${ }^{119}$ Another contrasting

\footnotetext{
${ }^{117}$ Richard White, Indians, Empires and Republics in the Great Lakes Region, 1650-1815 (Cambridge: Cambridge University Press, 1991 [1995]), p. 271.

${ }^{118}$ Carr, Marxism, Chapter 3.

${ }^{119}$ Barry Carr, "Mill Occupation and Soviets: The Mobilization of Sugar Workers in Cuba, 1917-1933," Journal of Latin American Studies 28 (Spring 1996), 129-58; "Identity, Class and
} 
example is Costa Rica, where the communist party (PC de CR) played a key role in organizing the rural banana workers of the Atlantic Coast in the strike against the United Fruit Company in 1934. Despite successfully mobilizing thousands of workers, the party failed to unite Mestizo and Afro-Caribbean laborers in common cause. ${ }^{120}$

These comparative examples highlight the diverse outcomes of communist organizational efforts in the early 1930s. A coffee picker in western El Salvador, a cotton worker in the Laguna, a cane cutter in eastern Cuba, and a banana picker in the Atlantic zone of Costa Rica had more in common with one another than they did with an industrial worker in New York or Manchester. But arguably, it was their differences that determined the distinct ways in which they perceived their social condition and the merits of their local communist party. Labor historians are paying closer attention to local variables, such as community and ethnicity, and are focusing on the cultural, rather than the institutional aspects of working peoples' lives and mobilizations. The case of the 1932 rebellion in El Salvador suggests that such a line of inquiry is not only valid, but also essential.

Furman University

ERIC CHING

Greenville, South Carolina

Nation: Black Immigrant Workers, Cuban Communism and the Sugar Industry, 1925-1934," Hispanic American Historical Review 78:1 (1998); and "From Caribbean Backwater to Revolutionary Opportunity: Cuba's Evolving Relationship with the Comintern, 1925-1934," in Tim Rees, ed., International Communism and the Communist International (Manchester: MVP, 1998), forthcoming.

${ }^{120}$ Philippe Bourgois, Ethnicity at Work: Divided Labor on a Central American Banana Plantation (Baltimore: The Johns Hopkins University Press, 1989); and Aviva Chomsky, West Indian Workers and the United Fruit Company in Costa Rica, 1870-1940 (Baton Rouge: Louisiana State University Press, 1996), Chapter' 9. 